\title{
Perilaku Asertif dan Kecenderungan Kenakalan Remaja Berdasarkan Pola Asuh dan Peran Media Massa
}

\author{
Sriyanto ${ }^{1}$, Aim Abdulkarim², Asmawi Zainul, Enok Maryani \\ Sekolah Pascasarjana Universitas Pendidikan Indonesia Bandung
}

\begin{abstract}
Theoretically the adolescent psychological development is a transition period which is marked by changes in biological, psychological and social aspects. Empirically, the increasing trend of juvenile delinquency is caused by the inability of the early adolescents to be assertive so that their personality become weak and they can easily fall into negative things. This study aimed at determining the extent to which environment and mass media have the influence on assertive behaviour and juvenile delinquency trend in Junior High School in West Java Province. The respondents of this research were 458 students of Junior High Schools in West Java. Questionnaire was used to collect the data. Samples were chosen by using stratified random sampling technique. Data analysis employed Structural Equation Modelling (SEM) with two-stages testing: measurement model and structural model, using Analysis of Moment Structure (AMOS). The results of this study revealed that all hypothetical statements have significant effects. The findings showed that the increasing level of students' assertive behaviour can decrease the tendency of juvenile delinquency in them.
\end{abstract}

Keywords: assertive behaviour, parenting, mass media, juvenile delinquency trend

\begin{abstract}
Abstrak. Penelitian ini secara teoretis dilandaskan pada perkembangan psikologi remaja sebagai masa transisi yang ditandai perubahan aspek biologis, psikologis, dan sosial. Secara empiris penelitian ini didasarkan atas meningkatnya fenomena kecenderungan kenakalan remaja karena ketidakmampuan para remaja awal untuk bersikap asertif sehingga kepribadiannya menjadi lemah dan sering terjerumus ke dalam hal-hal yang negatif. Penelitian ini bertujuan untuk mengetahui sejauh mana lingkungan dan media massa berpengaruh terhadap perilaku asertif dan kecenderungan kenakalan remaja pada Sekolah Menengah Pertama Negeri di Provinsi Jawa Barat. Pengumpulan data dilakukan menggunakan kuesioner terhadap 458 responden. Penentuan sampel menggunakan teknik stratified random sampling. Data yang terkumpul dianalisis dengan Structural Equation Modelling (SEM) melalui pengujian dua tahap yaitu measurement model dan structural model menggunakan aplikasi software Analysis Moment of Structure (AMOS). Hasil penelitian bahwa semua pernyataan hipotetik yang diajukan berpengaruh signifikan. Temuan dari penelitian adalah meningkatnya perilaku asertif peserta didik ternyata dapat menurunkan kecenderungan kenakalan remaja.
\end{abstract}

Kata kunci: perilaku asertif, pola asuh, media massa, kecenderungan kenakalan remaja

Munculnya fenomena kecenderungan kenakalan remaja (yang masih berstatus sebagai pelajar) akhir-akhir ini menjadi

\footnotetext{
${ }^{1}$ Korespondensi mengenai isi artikel ini dapat dilakukan melalui: sriyanto1907@gmail.com

2 Atau melalui: aimpkn@yahoo.com; perbo@indo.net.id; emaryani@yahoo.com
}

permasalahan yang mengkhawatirkan baik dari perspektif pendidikan, psikologi, sosial, maupun budaya. Kehidupan remaja yang ditandai oleh berbagai macam kenakalan remaja, adalah bukti lemahnya moralitas dan kepribadian usia remaja. Di Indonesia selama dasawarsa terakhir ini, menunjukkan adanya kecenderungan 
yang semakin serius tentang permasalahan remaja Indonesia khususnya masalah sosial, psikologi, budaya, dan moralitas. Sebagai contoh, gambaran tentang banyaknya remaja Indonesia mengalami masalah sosial yang ditunjukkan dalam bentuk perbuatan kriminal, asusila, dan pergaulan bebas; masalah budaya dalam bentuk kehilangan identitas diri, terpengaruh budaya barat; dan masalah degradasi moral yang diwujudkan dalam bentuk kurang menghormati orang lain, tidak jujur sampai ke usaha menyakiti diri seperti mengkonsumsi narkoba, mabukmabukan dan bunuh diri (Puspitawati, 2009, 2010).

Kenakalan remaja memiliki sifat psikis, interpersonal, antarpersonal, dan kultural sebab perilaku kenakalan selalu berlangsung dalam konteks antarpersonal dan sosio-kultural (Kartono, 2010). Individu menjadi faktor utama dalam memilih dan menentukan eksistensi dirinya dalam membentuk karakter agresif, asertif, atau pasif. Pendidikan selayaknya menjadi sarana yang efektif untuk mengembangkan kemampuan dan membangun karakter peserta didik, sebab pendidikan memberi pelajaran nilai-nilai kearifan dan budaya masyarakat. Selaras dengan hal itu maka, pendidikan yang bermakna dan bermutu pada dasarnya harus selalu mengacu ke masa depan. Pendidikan bermakna juga harus bersifat komprehensif dan holistik, untuk mempersiapkan masa depan peserta didik. Sebab peserta didik akan menghadapi kehidupan yang komplek karena tuntutan perkembangan ilmu pengetahuan dan teknologi.

Berkaitan dengan pendidikan, keluarga menjadi faktor yang penting dalam perkembangan psikologi dan sosial anak. Pola asuh dan komunikasi yang dilakukan orang tua dapat memberikan pengalaman pada masa kanak-kanak yang akan memengaruhi perkembangan berikutnya. Kemudian dalam konteks sosio-budaya, orang tua dengan sistem nilai-norma melaksanakan tugasnya menjalankan peran kedewasaan, termasuk menjadi pendidik terhadap anak dengan mewakili atau sebagai perantara (mediasi) dari dunia makna-nilai (abstrak namun bersifat imperatif-operasional) yang berwibawa atas dirinya dan juga orang dewasa umumnya.

Namun, kehidupan masyarakat modern saat ini yang serba kompleks sebagai hasil perkembangan teknologi modern, industrialisasi, dan juga mekanisasi dapat berdampak terhadap kehidupan sosial. Adaptabilitas masing-masing individu terhadap keadaan tersebut menjadi hal yang tidak mudah sebab dapat memunculkan konflik, kecemasan, dan kebimbangan jika individu tidak memiliki kontrol diri yang baik. Konflik dalam diri individu dapat berupa konflik eksternal yang terbu$\mathrm{ka}$, dan internal dalam batin yang tersembunyi dan tertutup sifatnya. Timbulnya konflik pada masyarakat modern didukung pula ketidaksiapan masyarakat dengan kemajuan teknologi informasi yang cepat, yang tidak diimbangi oleh perkembangan pola fikirnya. Globalisasi, kemajuan teknologi informasi dan komunikasi melalui internet, dan telepon seluler (ponsel) adalah fenomena masyarakat modern dengan segala kemudahan yang ditawarkan, tetapi juga berdampak luas bagi masyarakat baik positif maupun negatif. Dunia modern yang ditandai oleh perkembangan teknologi informasi dan komunikasi yang semakin maju, berdampak signifikan terhadap tata kehidupan manusia di berbagai aspek.

Penelitian (Gillen, 2003; Uyun \& Hadi, 2005; Sert, 2003; Marini \& Andriani, 2005; Sikone, 2007; Puspitawati, 2009) menunjukkan bahwa para remaja terjerumus ke 
dalam hal negatif seperti tawuran, narkoba, seks bebas, salah satunya disebabkan oleh kepribadian yang lemah yaitu ketidakmampuan para remaja untuk bersikap asertif. Perilaku asertif bagi remaja bermanfaat untuk memudahkan bersosialisasi dalam lingkungannya, menghindari konflik karena bersikap jujur dan terus terang, dan dapat menyelesaikan masalah yang dihadapi secara efektif. Kondisi ini dalam pandangan Habermas, disebut distorsi komunikasi yaitu ketidakmampuan para remaja memahami atau sengaja tidak mau untuk menyepakati aturan-aturan budaya, masyarakat, dan komunitas, sehingga para remaja terlibat dalam perilaku negatif. Padahal, dalam aturan-aturan tersebut dapat ditelusuri latar belakang sosial dan kultural yang memberikan kemungkinan membayangkan dirinya dalam posisi orang lain.

Filosofi asertivitas didasarkan pada satu premis bahwa setiap individu memiliki hak dasar yang sama sebagai pribadi dan sebagai bagian dari kelompok sosial. Asertivitas sebetulnya merupakan konsep yang agak samar untuk didefinisikan (Golden, 1978) sebab berada di antara dua perilaku ekstrim yang bertentangan yaitu perilaku pasif dan agresif (Wilson \& Gallois, 1993; Janda, 1996). Asertivitas merupakan kemampuan seseorang untuk mengekspresikan diri, pandangan-pandangan dirinya, dan menyatakan keinginan dan perasaan diri secara langsung, jujur, dan spontan tanpa merugikan diri sendiri dan melanggar hak orang lain. Asertivitas dalam perspektif pendidikan merupakan domain keterampilan sosial (social skills) diantara kerja sama (cooperation), tanggung jawab (responsibility), dan self-control (Sivin-Kachala \& Bialo, 2009), empathy (Elliot \& Gresham dalam Golden, 2002), problem behavior (Chong \& Li, Jen-Yi, 2008). Dengan demikian, asertivitas meru- pakan kemampuan untuk mengungkapkan hak dan kebutuhan secara positif dan konstruktif tanpa melanggar hak orang lain. Ciri seseorang yang memiliki perila$\mathrm{ku}$ asertif adalah hubungan yang dilakukan merasa lebih percaya diri, mendapatkan rasa hormat dari orang lain melalui jalinan komunikasi secara langsung, terbuka, dan jujur. Asertivitas bermanfaat bagi individu untuk menjaga kejujuran dalam komunikasi, mampu untuk mengendalikan diri, dan meningkatkan kemampuan dalam pengambilan keputusan.

Pendidikan sejatinya dapat menjadi wadah untuk mewariskan kebudayaan, dalam membentuk kepribadian dan karakter generasi muda. Secara sistematis pendidikan merupakan usaha sadar yang memiliki landasan filosofis, psikologis, sosiologis, dan kultural untuk mencapai tujuan yang diamksud. Apa yang tersirat dalam landasan tersebut bahwa pendidikan merupakan pilar utama untuk membangun peradaban suatu bangsa di atas fondasi budaya masyarakat. Terkait erat dengan landasan tersebut, maka tujuan pendidikan mensyaratkan pengembangan kemampuan dan intelektual, keterampilan, dan nilai peserta didik seperti yang tergambar dalam dimensi kemampuan kehidupan manusia. Dengan munculnya fenomena kecenderungan kenakalan remaja (yang masih berstatus sebagai pelajar) akhir-akhir ini menjadi permasalahan yang mengkhawatirkan baik dari perspektif pendidikan, psikologi, sosial, maupun budaya. Dari perspektif pendidikan persoalan tersebut sebetulnya menjadikan ironi, di satu sisi pendidikan seharusnya dapat membangun kepribadian, perilaku, dan karakter peserta didik, namun tidak sedikit kenakalan tersebut justru dilakukan ketika mereka masih berseragam sekolah. 
Berdasarkan latar belakang yang telah diuraikan, peneliti ingin mengetahui pengaruh pola asuh orang tua, media massa terhadap perilaku asertif dan kecenderungan kenakalan remaja. Bandura (1989) dalam studinya menjelaskan bahwa keluarga, kelompok masyarakat, dan media massa secara sistematis dapat membentuk pola ingatan yang tergambar dalam kebiasaan bertingkah laku individu melalui peniruan (imitating) dan pemodelan (modeling). Keluarga menjadi faktor yang penting dalam perkembangan psikologi anak. Orang tua juga memberikan dasar kehidupan emosi dan dasar kehidupan moral anak. Kehidupan emosional keluarga dapat menjamin perkembangan emosional anak dalam pembentukan pribadinya. Demikian juga dengan keteladanan orang tua dalam bertutur kata dan berperilaku sehari-hari akan menjadi wahana pendidikan moral bagi anak untuk membentuk manusia susila. Keluarga merupakan peletak dasar pendidikan akhlak dan pandangan hidup keagamaan. Sifat dan tabiat anak sebagian besar diambil dari kedua orang tua dan anggota keluarga yang lainnya.

Namun pada kenyataannya, orang tua seringkali memberikan model agresif secara fisik melalui hukuman fisik pada anaknya. Hal ini dilakukan dengan dalih untuk mendisiplinkan anaknya, padahal sejatinya secara bersamaan orang tua juga memberikan contoh agresif kepada anak (Myers, 2012). Studi Bandura dan Walter (1963) menemukan bahwa hukuman fisik yang dilakukan oleh para orang tua, akan berlanjut pada anak yang mendapatkan perlakuan kekerasan ketika anak tersebut telah menjadi orang tua. Hasil penelitian Scholte (1991) dalam Mönks, Knoers, dan Haditono (2006) juga menemukan remaja berusia 15 tahun yang terlibat perkelahian, mencuri, dan bentuk perilaku yang melanggar hukum sangat berhubungan dengan teman-teman sebaya (peers group) yang mengalami masalah, pengasuhan di rumah yang problematik, situasi pendidikan, dan masalah yang terjadi di sekolah. Model pengasuhan orang tua seringkali sebagai antitesa dari perilaku anak sendiri, dimana anak dapat memancing cara pengasuhan tertentu pada orang tua yang selanjutnya justru dapat memperdalam permasalahan.

Dunia modern yang ditandai oleh perkembangan teknologi informasi dan komunikasi yang semakin maju, berdampak signifikan terhadap tata kehidupan manusia di berbagai aspek. Tidak dapat dihindari, arus ini menyeret setiap orang ke dunia digital, dengan terminilogi yang sering disebut dengan virtual (Shields, 2012). Salah satu bentuk dunia digital terelaborasi dalam komunikasi melalui media massa. Bagian terpenting dari perkembangan media massa ini adalah jaringan internet, yang sudah masuk hingga ke pelosok daerah. Komunikasi melalui jaringan internet atau komunikasi virtual merupakan cara berkomunikasi dimana penyampaian dan penerimaan pesan dilakukan dengan melalui cyberspace. Bentuk komunikasi ini sangat digandrungi oleh kalangan remaja karena dapat ditemukan di mana saja dan kapan saja. Media komunikasi ini dengan berbagai kemudahan yang ditawarkan menjadikan komunikasi lebih efektif dan efisien dengan layanan fasilitas web, chatting, email, facebook, friendster, twitter, whats app dan fasilitas lainnya. Begitu banyak fasilitas yang ditawarkan dalam dunia maya untuk melakukan komunikasi, dan keberadaannya semakin membuat manusia tergantung. Siebert, dkk. (1963) mengemukakan bahwa empat teori media massa pada dasarnya mengacu pada satu pengertian media massa sebagai forum yang me- 
nyampaikan pandangannya tentang banyak hal yang terjadi di masyarakat. Media massa juga harus sebagai kontrol sosial, dan guru bagi masyarakat. Dengan demikian, media massa sebetulnya memiliki peran yang penting dalam membangun kepercayaan dan kredibilitas konsumen. Namun, hal ini berbeda dengan perkembangan media massa saat ini. Seperti dilaporkan Myers (2012) bahwa media berdampak pada perilaku terdapat tiga dasar pemikiran, yaitu (1) keterbangkitan fisik (arousal) yang dimunculkan karena melihat kekerasan, sebagai satu bentuk untuk menyalurkan tenaga pada perilaku lain; (2) penelitian juga menunjukkan bahwa melihat kekerasan bersifat membebaskan; dan (3) melihat kekerasan memicu perilaku agresif dengan mengaktifkan pikiran yang berhubungan dengan kekerasan (violence-related). Tayangan di televisi juga menimbulkan imitasi, yaitu mengulangi perilaku yang disaksikan melalui media.

Permasalahan tentang perilaku remaja dalam perspektif teori belajar meyakini bahwa lingkungan (keluarga dan kelompok) memberikan kontribusi yang penting dalam perkembangan perilaku menyimpang pada remaja. Bandura (1989) sebagai penggagas teori belajar sosial (social learning theory) mengemukakan bahwa agresivitas tidak hanya berasal dari dampak merasakan perbuatannya, tetapi juga dengan mengamati seseorang. Ide pokok Bandura merupakan pengembangan pemikiran dari Miller dan Dollard tentang perilaku meniru (imitative behavior) (Hergenhahn \& Olson, 2010). Bandura berhasil mengelaborasi proses belajar sosial dengan faktor kognitif dan perilaku, sehingga dapat memengaruhi seseorang. Menurut Bandura (1989), model yang terpampang dalam keluarga, kelompok masyarakat, dan media massa merupakan sarana yang efektif sebagai model untuk berperilaku agresif. Teori belajar sosial dari Bandura mendasarkan pada asumsi bahwa perilaku pada dasarnya ditentukan oleh lingkungan dan dapat dipelajari dengan membentuk asosiasi yang terjadi karena kebiasaan, refleksi, atau hubungan antara respon dengan penguatan yang memungkinkan dalam lingkungan (Kurniadi, 2001). Berdasarkan asumsi ini, jika perilaku agresif dipelajari, maka ada harapan untuk mengendalikannya (Myers, 2012).

Berdasarkan uraian di atas maka pengajuan pernyataan hipotesis yaitu: terdapat pengaruh signifikan positif pola asuh orangtua terhadap perilaku asertif, terdapat pengaruh signifikan negatif media massa terhadap perilaku asertif, terdapat pengaruh signifikan pola asuh orangtua terhadap kecenderungan kenakalan remaja, terdapat pengaruh signifikan media massa terhadap kecenderungan kenakalan remaja, dan terdapat pengaruh signifikan negatif perilaku asertif terhadap kecenderungan kenakalan remaja.

\section{Metode}

Paradigma penelitian dibangun di atas landasan pendekatan kuantitatif dengan desain survei untuk menjelaskan hubungan variabel yang memengaruhi perilaku asertif dan kecenderungan kenakalan remaja. Penelitian dilakukan di Provinsi Jawa Barat di 17 kabupaten dan sembilan wilayah kota. Subjek penelitian adalah siswa Sekolah Menengah Pertama (SMP) Negeri, sampel penelitian tersebar di 13 sekolah. Data dikumpulkan menggunakan angket ke 458 responden, dengan teknik stratified random sampling.

Uji coba instrumen dilakukan di dua sekolah dengan jumlah responden masingmasing sekolah 25 siswa dan 27 siswa. Operasionalisasi variabel pola asuh seba- 
gai alat ukur dalam pengumpulan data berdasarkan pada penjabaran konsep tentang bentuk dan proses interaksi antara orang tua dan anak dalam menanamkan nilai untuk memengaruhi perkembangan kepribadian yang terbentuk dari demandingness dan responsiveness terdiri dari aspek kasih sayang, tuntutan kedewasaan, komunikasi, dan kontrol. Data dikumpulkan menggunakan angket untuk mengetahui pengasuhan orang tua yang authoritative, authoritarian, permissive, dan uninvolved. Pengukuran dilakukan dengan skala Likert dengan rentang skor $1-5$. Instrumen variabel media massa digunakan untuk menjaring jenis media massa yang dimanfaatkan oleh responden, intensitas frekuensi pemanfaatan, dan konsumsi media massa oleh responden, dengan menggunakan skor $1-5$. Pengembangan instrumen variabel perilaku asertif diungkap dengan menggunakan skala asertivitas yang merupakan gabungan skala yang disusun dan diadaptasi dari The Rathus Assertiveness Schedule (RAS) yang juga digunakan oleh Afiatin (2003) untuk mengukur asertivitas pada remaja. Sedang variabel kecenderungan kenakalan remaja dikembangkan menjadi empat subvariabel yaitu kenakalan yang melawan status, kenakalan sosial yang tidak menimbulkan korban pihak lain, kenakalan yang menimbulkan korban fisik, dan kenakalan yang menimbulkan korban materi (Puspitawati, 2009). Pengukuran variabel kecenderungan kenakalan remaja menggunakan skala Likert dengan rentang skor $1-5$.

Data dianalisis dengan menggunakan analisis jalur (path analysis) model persamaan struktural (structural equation model) dengan bantuan software IBM SPSS AMOS 20.0 dan IBM SPSS Statistic 20.0. Model persamaan struktural merupakan model analisis yang menggunakan dua pengu- kuran, yaitu (a) persamaan pengukuran (measurement model), dan (b) persamaan struktural (structural model). Measurement model menggambarkan hubungan antara variabel laten dengan indikator-indikatornya, sedangkan structural model menggambarkan hubungan antar variabel-variabel laten atau antar variabel eksogen dengan variabel laten (Maruyama, 1998; Schumacker \& Lomax, 2004; Santoso, 2007, Marcoulides \& Kyriakides, 2010). Langkah-langkah dalam analisis ini meliputi: (1) Pengembangan diagram jalur; Membuat persamaan struktural; Memilih matrik input dan estimasi model; (4) Uji asumsi statistik (kriteria sampel dengan Maximum Likelihood (ML) harus besar, data terdistribusi normal dengan signifikansi 0,01 ; tidak terdapat data outlier, dan tidak terdapat hubungan variabel secara multikoliniaritas dan singularitas); dan (5) Pengujian model pengukuran (measurement model), melalui confirmatory factor analysis (CFA), analisis hubungan indikator dengan konstruk (convergent validity: variance extracted, construct reliability; dan discriminate validity); dan structural model. Hubungan kausalitas antar variabel dapat digambarkan dalam diagram jalur (Gambar 1).

\section{$\mathrm{H}$ a s i 1}

Instrumen yang sudah diuji validitas dan reliabilitas, disebarkan ke 458 responden yang menjadi sampel penelitian. Penyebaran kuesioner dilakukan dengan cara personally administrered questionnaire. Teknik ini digunakan dengan tujuan agar kuesioner yang disebarkan dapat kembali $100 \%$, sebab responden mengisi langsung kemudian dikembalikan. Setelah seluruh kuesioner terkumpul, langkah selanjutnya adalah mengecek kelengkapan pengisian kuesioner oleh responden. Hasil seleksi data yang memenuhi syarat kelengkapan 


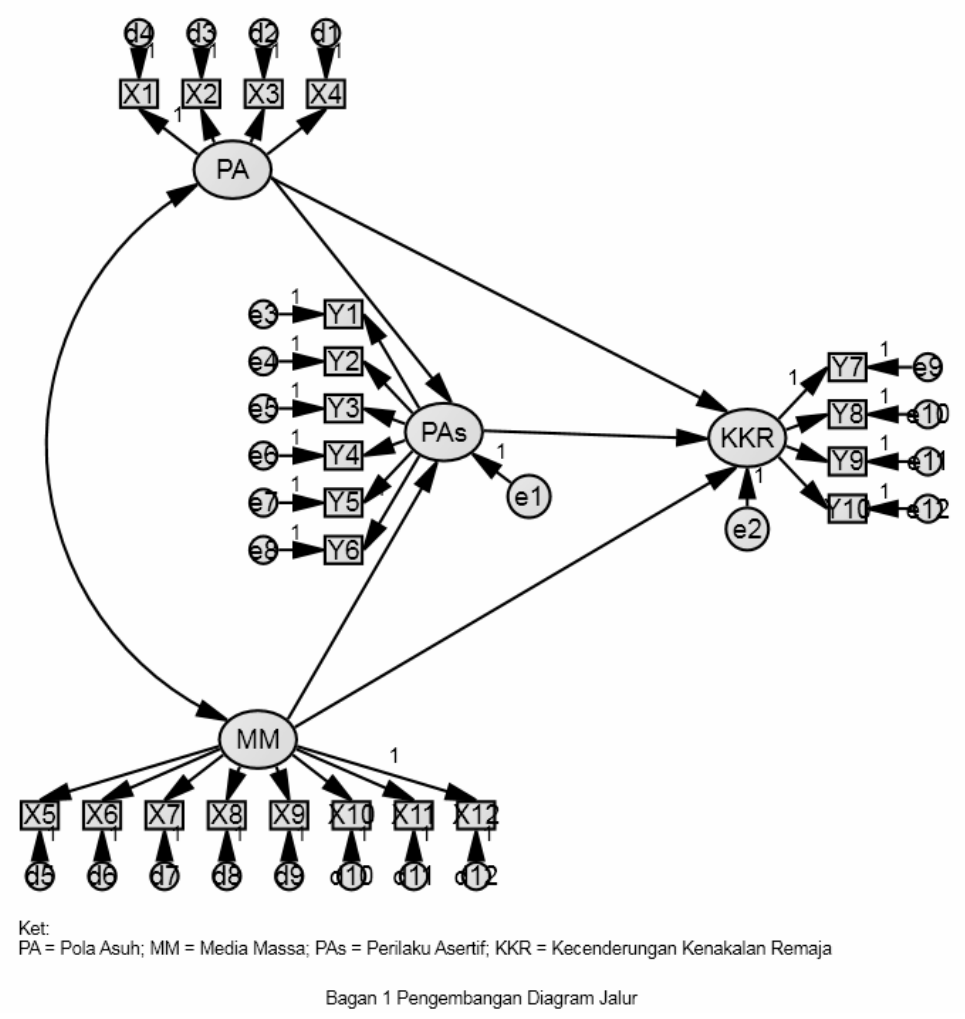

Keterangan: $\mathrm{PA}=$ Pola Asuh; $\mathrm{MM}=$ Media Massa; $\mathrm{PAs}=$ Perilaku Asertif; KKR = Kecenderungan Kenakalan Remaja

Gambar 1. Pengembangan Diagram Jalur

sebanyak 446 responden (97,38\%), dan data sisanya didrop.

Hasil uji persyaratan dalam SEM dengan bantuan software IBM SPSS AMOS 20.0 adalah nilai multivariate critical ratio (CR) sebesar 2,393. Nilai ini berada pada rentang -2,58 sampai dengan 2,58 pada taraf signifikansi 0,05 , sehingga dapat disimpulkan data terdistribusi normal secara multivariat. Evaluasi outliers data berdasarkan hasil observation farthers from the centroid (Mahalanobis distance) terdapat data yang lebih besar dari nilai $\chi 2=62,487$ yaitu observation number 52 , sehingga data tersebut didrop. Sedangkan untuk mendeteksi multikoliniaritas yaitu melalui statistik condition number $(\mathrm{CN})$ matriks covariance yaitu sebagai rasio nilai eigenvalue maksimal dan eigenvalue minimal. Berdasarkan teks output diperoleh koefisien determinan matriks covarian jauh lebih besar dari nol, hal ini mengindikasikan variabel tidak terdapat multikoliniaritas sempurna.

Tahap pengujian kelayakan model dilakukan melalui dua tahap yaitu pengujian measurement model dan structural model. Pengujian validitas measurement model, pengujian melalui goodness of fit (GOF) dilakukan untuk mengetahui seberapa besar variabel manifest (indikator) memberikan dukungan terhadap variabel latent (konstruk), dengan kata lain seberapa fit model dengan data yang diperoleh dalam penelitian. Berdasarkan hasil uji statistik menggunakan IBM SPSS AMOS 20.0 uji kesesuaian model goodness of fit hasil revisi maka nilai critical ratio (CR) dari masingmasing variabel pola asuh orangtua, media massa, perilaku asertif, dan kecende- 
rungan kenakalan remaja memberikan nilai $>2,58$. Nilai regression weigths untuk masing-masing variabel ini dapat disimpulkan bahwa masing-masing indikator atau variabel manifest memberikan dukungan terhadap variabel laten (konstruk). Sedangkan uji signifikansi bobot faktor setelah di standardized regression weights estimasi nilai loading factor dari konstruk pola asuh orang tua, media massa, perila$\mathrm{ku}$ asertif, dan kecenderungan kenakalan remaja lebih besar dari 0,50, maka dapat disimpulkan bahwa indikator signifikan menyusun variabel laten pola asuh orang tua, media massa, perilaku asertif, dan kecenderungan kenakalan remaja.

Setelah model pengukuran dianalisis melalui confirmatory factor analysis, dan hasil analisis menunjukkan bahwa masing-masing variabel dapat digunakan untuk mendefinisikan sebuah konstruk laten, maka sebuah full-model SEM dapat dianalisis. Berdasarkan hasil uji kesesuaian model maka belum didapat model yang fit, sehingga perlu dilakukan revisi (penyesuaian model). Setelah model diketahui kriteria standar dengan nilai chi-square, probability, GFI, CFI, AGFI, RMSEA, CMIN/DF, TLI memenuhi kriteria cut value, maka dapat dikatakan model fit. Kriteria ini dapat juga digunakan untuk menguji pengaruh langsung (direct effect), pengaruh tidak langsung (indirect effect), dan pengaruh total (total effect). Hasil uji analisis pengaruh langsung, pengaruh tidak langsung, dan pengaruh total, tertera pada Tabel 1.

Tabel 1 menunjukkan hubungan antar variabel terdapat hubungan yang negatif dan positif. Dari hasil uji statistik, maka hasil uji hipotesis dengan taraf signifikansi 0,05 dapat disimpulkan bahwa pola asuh orang tua berpengaruh signifikan positif terhadap perilaku asertif. Pengaruh positif pola asuh terhadap perilaku asertif dapat
Tabel 1

Pengaruh Langsung, Tidak Langsung, dan Pengaruh Total

\begin{tabular}{lrrrr}
\hline $\begin{array}{l}\text { Pengaruh } \\
\text { Langsung }\end{array}$ & MM & PA & PAs & KKR \\
\hline PAs & -.136 & .159 & .000 & .000 \\
KKR & .187 & -.316 & -.181 & .000 \\
Pengaruh tidak langsung & & & \\
KKR & .025 & -.029 & .000 & .000 \\
Pengaruh total & & & & \\
PAs & -.136 & .159 & .000 & .000 \\
KKR & .212 & -.345 & -.181 & .000 \\
\hline
\end{tabular}

Sumber: Diolah dari Data Primer dengan IBM SPSS AMOS Graphic 20

Keterangan:

PAs = Perilaku Asertif

KKR $=$ Kecenderungan Kenekalan Remaja

$\mathrm{MM}=$ Media Massa

$\mathrm{PA}=$ Pola Asuh orang tua

digambarkan bahwa orang tua menjadi faktor penting dalam pembentukan kepribadian anak, yang akan menentukan perkembangan selanjutnya. Kepribadian orangtua, sikap dan cara hidupnya merupakan unsur pendidikan yang secara langsung dan tidak langsung menjadi model bagi anak yang sedang tumbuh. Hubungan antara pengasuhan orang tua dengan dampak perkembangan kepribadian seperti dijelaskan oleh Baumrind (Shafer \& Kipp, 2010) bahwa gaya pengasuhan otoritatif memberikan dampak terhadap perkembangan kognitif dan kompetensi sosial yang tinggi. Untuk masa remaja gaya pengasuhan ini dampak yang ditimbulkan adalah sikap percaya diri, keterampilan sosial yang baik, moral yang kuat (sikap sosial yang konsisten) dan prestasi akademik yang tinggi. Pengasuhan model otoritarian berdampak pada anak-anak terhadap perkembangan pengetahuan dan kompetensi sosial yang sedang. Hasil gaya pengasuhan ini untuk usia remaja biasanya adalah prestasi akademik dan 
keterampilan sosialnya kurang begitu menonjol, namun lebih baik jika dibandingkan dengan pengasuhan permisif (permissive). Pengasuhan permissive berdampak pada perkembangan kognitif dan kompetensi sosial rendah pada anak-anak, sedang ketika memasuki masa remaja pengasuhan ini mengakibatkan prestasi akademik dan kontrol diri yang rendah.

Hasil pengujian hipotesis menunjukkan bahwa pola asuh berpengaruh positif terhadap perilaku asertif peserta didik, sebaliknya pola asuh berpengaruh secara signifikan (negatif) terhadap kecenderungan kenakalan remaja. Secara statistik besarnya pengaruh variabel pola asuh terhadap perilaku asertif peserta didik mencapai 0,159 , sedangkan besarnya pengaruh langsung variabel pola asuh terhadap kecenderungan kenakalan remaja -0,316. Hasil uji hipotesis dapat dikemukakan bahwa pengaruh pola asuh orangtua berpengaruh negatif dan signifikan terhadap kecenderungan kenakalan remaja. Sementara itu pengaruh media massa terhadap perilaku asertif secara statistik sebesar 0,136 . Sebaliknya media massa berpengaruh positif dan signifikan terhadap kecenderungan kenakalan remaja yaitu sebesar 0.187. Hasil uji hipotesis variabel perilaku asertif terhadap kecenderungan kenakalan remaja dapat dibuktikan dengan angka statistik mencapai $-0,181$. Adanya hubungan yang negatif ini berarti jika perilaku asertif pada peserta didik tinggi maka kecenderungan kenakalan remaja akan rendah, sehingga perilaku asertif dapat dijadikan sebagai mediator untuk mengurangi kenakalan remaja. Dengan demikian kelima pernyataan hipotesis dalam penelitian ini dapat diterima, sebab hasil uji statistik memberikan nilai $C R \geq 1,96$ untuk taraf signifikansi 0,05\%.

\section{Diskusi}

Hasil uji statitik menyatakan bahwa hipotesis pola asuh orang tua berpengaruh signifikan positif terhadap perilaku asertif, sementara pola asuh orang tua berpengaruh signifikan negatif terhadap kecenderungan kenalan remaja. Hal ini berlaku sebaliknya dengan variabel media massa yang berpengaruh signifikan negatif terhadap perilaku asertif, namun berpengaruh signifikan positif terhadap kecenderungan kenakalan remaja. Pernyataan hipotesis terakhir membuktikan bahwa perilaku asertif berpengaruh signifikan negatif terhadap kecenderungan kenakalan remaja.

Keluarga merupakan kelompok sosial terkecil dan bersifat abadi, yang dikukuhkan oleh pernikahan untuk memberikan pengaruh keturunan dan lingkungan sebagai dimensi penting bagi anak. Keluarga juga menjadi tempat penting di mana anak memperoleh dasar dalam membentuk kemampuan agar mampu bertahan dan beradaptasi dengan lingkungan yang lebih besar yaitu masyarakat (Gunarsa \& Gunarsa, 2011). Di dalam keluarga hubungan antar anggota keluarga dan kehidupan emosi saling berpengaruh. Berkaitan dengan hal tersebut maka fungsi dari keluarga menurut Gunarsa dan Gunarsa (2011) adalah mendapatkan keturunan dan membesarkan anak; memberikan afeksi atau kasih sayang, dukungan dan keakraban; mengembangkan kepribadian; mengatur pembagian tugas, menanamkan kewajiban, hak dan tanggung jawab; mengajarkan dan meneruskan adat istiadat, kebudayaan, agama, dan sistem moral kepada anak. Oleh karena itu suasana keluarga yang harmonis dan sejahtera dalam suasana keakraban akan menumbuhkan pribadi-pribadi yang mantap dan baik. 
Orang tua dalam pengasuhan memiliki peran yang sangat penting terhadap perkembangan kepribadian dan perilaku anak. Para ahli psikologi perkembangan (Shaffer \& Kipp, 2010; Benson \& Haith, 2009; Weiner, 2003; Santrock, 2007; Hurlock, 1998) menjelaskan bahwa dalam keluarga terjadi hubungan perkawinan, pengasuhan, dan perilaku anak yang saling memengaruhi baik secara langsung maupun tidak langsung. Beberapa penelitian menemukan bahwa keluarga yang perkawinannya bahagia akan lebih peka, responsif, hangat, dan penyayang terhadap anak-anaknya, dibandingkan dengan keluarga yang perkawinannya tidak bahagia. Perilaku asertif yang memiliki karakteristik tegas, jujur, terbuka, dan menghargai hak-hak orang lain, dapat dibentuk melalui pola asuh orang tua otoritatif. Secara empiris pengaruh pola asuh terhadap perilaku anak juga didukung hasil penelitian Martinez, Garcia, dan Yubero (2007) bahwa pola asuh dapat mempengaruhi tingkat kepercayaan diri (self esteem) dan prestasi akademik anak - anak usia 11 - 15 tahun di Brazil. Penelitian Turner, Chandler, dan Heffer (2009) bahwa pola asuh berpengaruh terhadap masalah psikologi anak (bersikap agresif) dan prestasi akademik. Sehingga dapat disimpulkan bahwa dalam keluarga yang hubungannya terjalin dengan baik memengaruhi perila$\mathrm{ku}$, perkembangan kepribadian, dan emosi anak.

Hasil penelitian sebelumnya yang dilakukan oleh Astiwi (2007) menunjukkan bahwa terdapat perubahan pada diri remaja yang meliputi aspek kognitif, afektif, dan behavioral setelah para remaja membaca media. Aspek kognitif berhubungan dengan faktor durasi membaca, aspek afektif berhubungan dengan pemilihan rubrik yang dibaca oleh remaja, sedang aspek behavioral berhubungan dengan pemilihan rubrik yang dibaca. Penelitian Wijayanti (2008) membuktikan bahwa variabel tingkat pandangan terhadap tayangan sinetron mempunyai hubungan yang positif dan signifikan dengan variabel tingkat perilaku asertif remaja. Penelitian ini sejalan dengan penelitian Arslan (2012), Malamuth dan Check (1981), Muslich (2008), Bennett (1982) bahwa peran media massa berpengaruh terhadap perilaku remaja, dan salah satunya adalah faktor ekspos berlebihan terhadap kekerasan di media.

Media massa pada dasarnya jika berada di tangan yang benar dapat memberikan informasi untuk mengembangkan ilmu dan pengetahuan, tetapi jika berada di tangan yang salah dapat berdampak negatif bagi penggunanya. Kemajuan ilmu dan teknologi berperan sangat penting terhadap perkembangan media massa, dalam waktu yang relatif singkat informasi tentang berbagai peristiwa di belahan dunia dapat dihadirkan langsung dalam waktu yang bersamaan dengan kejadian, dan di tempat yang berbeda dari tempat kejadian. Media massa saat ini memiliki peran yang sangat penting sebagai proses transformasi nilai dan norma baru bagi remaja. Hasil interpretasi penelitian Elizabeth Noelle-Nuemann (Littlejohn \& Foss, 2008), menunjukkan bahwa media memiliki efek yang sangat kuat dalam membentuk opini publik.

Bloom dkk. (1985) menjelaskan bahwa individu yang tingkat asertivitasnya tinggi dapat menjadi pertahanan diri yang efektif dan adaptif, mampu mengenal diri sendiri dengan baik, mengetahui kekurangan dan kelebihan dirinya, sehingga mampu merencanakan tujuan hidupnya, mempunyai rasa percaya diri, dan mampu mengambil keputusan. Penelitian sebelumnya secara empirik (Lumley, 2001; Trudeau dkk., 2003; Sert, 2003; Sipayung, 2007; Gillen, 
2003; Schwartz, 2006; Amat \& Mahmud, 2009; Afiatin, 2003) mendukung penelitian ini. Adanya pengaruh negatif dari pola asuh orang tua terhadap kecenderungan kenakalan remaja dalam penelitian ini menunjukkan bahwa semakin baik pengasuhan orang tua yang dirasakan oleh anak maka semakin rendah tingkat kenakalan remaja pada peserta didik. Temuan ini sejalan dengan hasil penelitian yang dilakukan oleh Cohen dan Rice (1997), Kusmierski, Nichols, dan McDonell (2001), Afiatin (2003), menyatakan bahwa hubungan diadik yang baik dalam keluarga berpengaruh terhadap meningkatnya perkembangan psikologi remaja, dan dapat menurunkan perilaku agresif. Penelitian ini juga mendukung hasil studi empirik yang dilakukan oleh Astuti (2004), Puspitawati (2006), yang menunjukkan bahwa pengasuhan yang dilakukan orang tua berpengaruh signifikan terhadap kecenderungan kenakalan remaja. Sumbangan terbesar terhadap kecenderungan kenakalan remaja, dalam penelitian Astuti (2004), diberikan oleh pengasuhan orang tua yang menjalankan gaya pengasuhan permisif, yaitu terlalu membiarkan dan memberikan kebebasan secara berlebihan kepada anak. Sedangkan sumbangan yang paling lemah adalah gaya pengasuhan demokratis.

\section{Kesimpulan}

Berdasarkan hasil analisis dan pembahasan terhadap hasil penelitian dapat disimpulkan pertama, bahwa pembentukan sikap dan perilaku asertif sangat penting pada diri remaja sebab masa ini merupakan masa yang menentukan bagi perkembangan kepribadian selanjutnya. Perilaku asertif memiliki pengaruh yang signifikan negatif terhadap kecenderungan kenakalan remaja. Perilaku dibentuk melalui konteks sosial yang dapat dipelajari baik seba- gai hasil reinforcement maupun motivasi intrinsik itu sendiri.

Kedua, pola hubungan dan komunikasi orang-tua dengan anak didasarkan pada hubungan yang mendorong anak untuk mandiri dan diperlakukan secara sejajar oleh seluruh keluarga, tetapi masih menerapkan batas tertentu dan kendali pada tindakan anak. Seringkali karena pengetahuan dan otoritas yang dimiliki orangtua, interaksi orangtua dengan anak terjadi dominasi orangtua untuk mengajar anak bagaimana menyesuaikan diri dengan peraturan dan regulasi. Perbedaan hubungan dan komunikasi di dalam dan di luar keluarga, dapat menimbulkan persepsi negatif terhadap keluarga. Remaja cenderung belajar memformulasikan dan menyatakan pendapat mereka, menghargai sudut pandang teman sebaya, menegosiasikan solusi atas perselisihan secara kooperatif, dan mengubah standar perila$\mathrm{ku}$ yang dapat diterima secara bersama. Hubungan dalam lingkungan seperti ini tentu saja dapat bersifat negatif maupun positif.

Ketiga, media massa berpengaruh terhadap perilaku asertif dan kecenderungan kenakalan remaja. Pesatnya perkembangan teknologi informasi, menempatkan media massa sebagai bagian penting dalam kehidupan anak modern. Hal ini sejalan dengan teori yang dikemukakan oleh McQuail bahwa media memiliki pengaruh yang kuat terhadap pembentukan perila$\mathrm{ku}$. Melalui media seseorang mendapatkan informasi dan pengetahuan yang membentuk persepsi.

\section{Kepustakaan}

Afiatin, T. (2003). Pengaruh Program Kelompok AJI dalam Peningkatan Harga Diri, Asertivitas, dan Pengetahuan Mengenai NAPZA untuk Prevensi Penyalahgunaan 
NAPZA pada Remaja. (Disertasi tidak dipublikasikan). Fakultas Psikologi Universitas Gadjah Mada, Yogyakarta.

Amat, S., \& Mahmud, Z. (2009). "Hubungan antara Ketegasan Diri dan Kepuasan Hidup dalam Kalangan Pelajar Institusi Pengajian Tinggi (The Relationship between Assertiveness and Satisfaction with Life Among Students at a Higher Learning Institution)", Jurnal Pendidikan Malaysia, $34(2), 49-65$.

Arslan, D. O. (2012). Perbedaan Perilaku Asertif dan Konformitas Antara Etnis Cina dengan Etnis Jawa (Penelitian Pada Siswa SMA Sedes Sapentiae Semarang, (Tesis tidak dipublikasikan). Universitas Negeri Semarang.

Astiwi, H. (2007). Pola Membaca Majalah Remaja dan Pengaruhnya Terhadap Perilaku Remaja (Kasus Siswa Sekolah Menengah Umum Negeri 2 Bogor, Propinsi Jawa Barat). (Skripsi tidak dipublikasikan). Prodi Komunikasi dan Pengembangan Masyarakat Fakultas Pertanian IPB.

Bandura, A. (1989). Social cognitive theory. In R. Vasta (Ed.), Annals of Child Development. Vol. 6. Six Theories of Child Development, 1-60.

Bandura, A., \& Walters, R. H. (1963). Social Learning and Personality Development, New York: Holt Rinehart Sr Winston.

Baran, S. J., \& Davis, D. K. (2009). Mass Communication Theory: Foundations, Ferment, and Future, $5^{\text {th }}$ Edition, Boston: Wadsworth Cengage Learning.

Bennett, T. (1982). "Theories of The Media, Theories of Society", in Michael Gurevitch, eds., Culture, Society and The Media, London: Methuen.
Benson, J. B., \& Haith M. M. (2009). Social and Emotional Development in Infancy and Early Childhood, Oxford: Elsevier.

Bloom, L. Z., Coburn, K., \& Pearlam, J. (1985). The Assertive Woman, New York: Dell Publishing Co. Inc.

Chong, J. Y., \& Li, Jen-Yi. (2008). Social Skills in Children with Special Needs, With and Without Mainstream Education in Singapore, Singapore: National Institute of Education, Nanyang Technological University.

Cohen, D. A., \& Rice, J. (1997). Parenting Styles, Adolescent Substance Use, and Academic Achievement. Journal of Drug Education, 27, 199 - 211.

Gillen, T. (2003). Assertiveness, London: Management Shapers, Chartered Institute of Personnel and Development (CIPD).

Golden, L. (2002). Evaluation of the Efficacy of a Cognitive Behavioral Program for Offenders on Probation: Thinking for a Change, Dallas: University of Texas Southwestern Medical Center.

Golden, M. (1978). A Suggested Measure of Cognition Within the Context of Assertion, A Thesis of Department of Psychology, Presented in Partial Fulfillment of the Requirements for the Degree of Doctor of Philosophy at Concordia University, Montreal, Quebec: Concordia University: unpublished.

Gunarsa, S., \& Gunarsa, Y. S. (2011). Psikologi Praktis: Anak, Remaja dan Keluarga. Jakarta: PT BPK Gunung Mulia.

Hergenhahn, B. R., \& Olson, M. H. (2008). Theories of Learning, Terjemahan, Jakarta: Kencana. 
Hidayat, S. (2004). Hubungan Perilaku Kekerasan Fisik Ibu Pada Anaknya Terhadap Munculnya Perilaku Agresif Pada Anak SMP, Jurnal PROVITAE, I(1), 83 - 92.

Hurlock, E. B. (1998). Perkembangan Anak, Jilid 2, Terjemahan: M. Meitasari Tjandrasa, Jakarta: Erlangga.

Janda,L. (1996). The Psychologist's Book of Self-Test, 25 Love, Sex, Intelligence, Career, \& Personality Test, New York: Penguin Putnam Inc.

Kartono, K. (2010). Patologi Sosial 2: Kenakalan Remaja, Cetakan ke-9, Jakarta: Rajawali Pers.

Kurniadi, O. (2001). “Pengaruh Komunikasi Keluarga terhadap Prestasi Belajar Anak", MediaTor, 2(2), 267 - 290.

Kusmierski, S., Nichols, J., \& McDonell, R. (2001). “Do Parenting Styles Influence Alcohol Use and Binge Drinking During High School and College?, Department of Psychology. Diunduh dari:

www.murphylibrary.uwlax.edu/kusm ierski-nichols-, tanggal 9-5-2012.

Littlejohn, S. W., \& Foss, K. A. (2008). Theories of Human Communictaion, $9^{\text {th }}$ Edition, Belmont: Thomson Higher Education.

Lomax, R. G. (2010). Structural Equation Modeling: Multisample Covariance and Mean Structures, dalam Gregory R. Hancock \& Ralph O Mueller, (2010). The Reviewer's Guide To Quantitative Methods in The Social Science, New York and London: Routledge.

Lumley, V. A. (2001). An Assessment of Assertion Skill Among Adult With Mild Mental Retardation, Dissertation Submitted to the Eberly College of Arts and Sciences at West Virginia University in Partial Fulfillment of the Requirements for the Degree of
Doctor of Philosophy in Psychology, Morgantown: Departement of Psychology.

Malamuth, N. M., \& Check, J. V. P. (1981). The Effect of Mass Media Exposure on Acceptance of Violence Against Women: A Field Experiment, Journal of Research in Personality, 15(4), 436 - 446.

Marcoulides, G. A., \& Kyriakides, L. (2010). Structural Equation Modelling Techniques". Dalam Creemers, Bert P.M., Kyriakides, Leonidas, \& Sammons, Pam, (2010) Methodological Advances in Educational Effectiveness Research, London and New York: Routledge.

Marini, L., \& Andriani, E. (2005). Perbedaan Asertivitas Remaja Ditinjau dari Pola Asuh Orang Tua", PSIKOLOGIA, $\mathrm{I}(2)$

Martinez, I., Garcia, J. F., \& Yubero, S. (2007). Parenting Styles and Adolescents' self-esteem in Brazil, Psychology Reports, 100, 731-745.

Maruyama, G. M. (1998). Basic of Structural Equation Modeling, California, London, New Delhi: SAGE Publication Inc.

Maruyama, G. M. (1998). Basic of Structural Equation Modeling, California, London, New Delhi: SAGE Publication Inc.

Mönks, F. J., Knoers, A. M. P., \& Haditono, S. R. (2006). Psikologi Perkembangan Pengantar dalam Berbagai Bagiannya, Yogyakarta: Gadjah Mada University Press.

Muslich, M. (2008). Kekuasaan Media Massa Mengonstruksi Realitas, Bahasa dan Seni, 36(2).

Myers, D. G. (2012). Psikologi Sosial, Social Psychology, Terjemahan: Aliya Tusyani dkk., Jakarta: Salemba Humanika.

Puspitawati, H. (2006). Pengaruh Faktori Keluarga, Lingkungan Teman dan Seko- 
lah Terhadap Kenakalan Pelajar di Sekolah Menengah Lanjutan Tingkat Atas (SLTA) di Kota Bogor, (Disertasi tidak dipublikasikan) Program Studi Gizi Masyarakat dan Sumber Daya Keluarga, Institut Pertanian Bogor, Bogor.

Puspitawati, H. (2009). Pengaruh Komunikasi Keluarga, Lingkungan Teman Dan Sekolah Terhadap Kenakalan Pelajar Dan Nilai Pelajaran Pada Sekolah Menengah 01 Kota Bogor, PEKSOS: Jurnal llmiah Pekerjaan Sosial, $7(2)$.

Puspitawati, H. (2010). Pengaruh Karakteristik Sosial Ekonomi Keluarga Terhadap Pola Asuh Belajar Siswa Sekolah Dasar Dan Menengah Pertama, Jurnal Ilmu Keluarga \& Kons., 3(1) 46-55.

Santoso, S. (2007). Structural Equation Modelling, Konsep dan Aplikasi dengan AMOS, Jakarta: PT. Elex Media Komputindo.

Santrock, J. W. (2007). Perkembangan Anak Jilid 2, Edisi 11, Terjemahan, Jakarta: Erlangga.

Schumacker, R. E., \& Lomax, R. G. (2004). A Beginner's Guide to Structural Equation Modeling, $2^{\text {nd }}$ Edition, New Jersey: Lawrence Erlbaum Associates Inc.

Schwartz, A. E. (2006). Assertiveness: Responsible Communication, United States of America: Andrew E. Schwartz \& Associates.

Sert, A. G. (2003). The Effect of an Assertiveness Training on the Assertiveness and Self-Esteem Level of $5^{\text {th }}$ Grade Children, A Thesis Submitted to The Graduate School of Social Sciences of Middle East Technical University, in Partial Fullfilment of The Requirements for the Degree of Master of Science in The Department of Educational Sciences, June 2003.
Shaffer, D. R., \& Kipp, K. (2010). Developmental Psychology, Childhood $\mathcal{E}$ Adolescence, $8^{\text {th }}$ Edition, Wadsworth: Cengage Learning.

Shields, R. (2012). Virtual, Sebuah Pengantar Komprehensif, Terjemahan, Bandung: Jalasutra.

Siebert, F. S., Schramm, W., \& Peterson, T. (1956). Four Theories of the Press: The Authoritarian, Libertarian, Social Responsibility, and Soviet Communist Concepts of What the Press Should Be and Do, University Illinois Press.

Sikone, S. (2007). Menanamkan Sikap Asertif di Sekolah, Diunduh dari: http://id. shvoong.com/social-sciences/1685406menanamkan-sikap-asertif-disekolah/\#ixzz1a0PzgKIW, tanggal 6/1/2012.

Sipayung, M. (2007). Pengaruh Pelatihan Asertivitas terhadap Peningkatan Harga Diri, Jurnal Pendidikan Matematikan dan Sains, 2(1), 33-37.

Sivin-Kachala, J., \& Bialo, E. (2009). IESD Comprehensive Technical Report, Evaluation of the Social Skills of Full-Time, Online Public School Students, New York: Interactive Educational System Design (IESD) Inc.

Trudeau, L., Lillehoj, C., Spoth, R., \& Redmond, C. (2003). "The Role of Assertiveness and Dicesion Making in Early Adolescent Substance Initiation: Mediating Processes", Journal of Research on Adolescence, 13(3), 301 328.

Turner, E. A., Chandler, M., \& Heffer, R. W. (2009). The Influence of Parenting Styles, Achievement Motivation, and Self-Efficacy on Academic Perpormance in College Students, Journal of College Student Development, 50(3), 337 -346 . 
Uyun, Q., \& Hadi, S. (2005). "Pelatihan Asertivitas untuk Meningkatkan Ketahanan Isteri terhadap Tindak Kekerasan Suami", SOSIOSAINS, 18(1).

Weiner, I. B., Editor-in-Chief, (2003). Handbook of Psychology, Vol. 6 Developmental Psychology, New Jersey: John Wiley \& Sons Inc.
Wijayanti, R. (2008). Hubungan Menonton Tayangan Sinetron "Virgin" di ANTV dengan Perilaku Asertif Remaja, MediaKOM, 1(1), 50 - 61 .

Wilson, K., \& Gallois, C. (1993). Assertion E Its Social Context, Oxford: Pergamon Press Ltd. 